Quebec Cooperative Study of

Friedreich's Ataxia

\title{
Antagonism by Taurine of Morphine Induced Growth Hormone Secretion
}

\author{
R. COLLU, G. CHARPENET AND M. J. CLERMONT
}

SUMMARY: The intraperitoneal (IP) or intraventricular (IVT) administration of small amounts of taurine did not modify pentobarbital-induced sleep or pituitary hormone release. However, the drastic increment in plasma $\mathrm{GH}$ values induced by morphine administration was completely blocked by the IVT injection of the amino acid. Whether taurine plays a physiological role in the control of $G H$ secretion is highly speculative.

RÉSUMÉ: Alors que l'administration de petites quantités de taurine, soit i.p. soit IVT, n'empêche pas le sommeil ni la libération des hormones antehypophysaires induits par le pentobarbital, l'élévation drastique des taux plasmatiques de GH induite par la morphine est complètement bloquée par l'injection IVT de cet acide aminé. La possibilité que la taurine ait un rôle physiologique dans le contrôle de la sécrétion du GH est encore très hypothétique.

From: Centre de Recherche Pédiatrique, Hôpital Sainte-Justine and Université de Montréal, Montréal, Québec.

Reprint requests for the complete supplement on Friedreich's Ataxia (Phase Two, Part One) to: Dr. André Barbeau, Clinical Research Institute of Montreal, 110 Pine Avenue West, Montreal. Quebec, Canada H2W IR7.
Taurine (2-aminoethanesulfonic acid) is an amino acid present in several animals including man (Jacobsen and Smith, 1968; Huxtable and Barbeau, 1976). Its concentration in the central nervous system (CNS) is particularly high, but unevenly distributed within the various regions (De Guglielmone and Gomez, 1966). In particular, high concentrations are found in the retina (Bonaventure et al., 1974), pineal gland (Guidotti et al., 1972), hypothalamus (Crabai et al., 1974), striatum and cerebellum (Perry et al., 1971). Taurine meets some of the criteria of an inhibitory neurotransmitter (Davidson and Kaczmarek, 1971). In addition, it has been shown that taurine can modify psychomotor activity in the rat (Baskin et al., 1974) and markedly reduce the CNS-depressant effect of ethanol in mice (Iida and Hikichi, 1976). It may be involved in the pathogenesis of Friedreich's ataxia (Lemieux et al., 1976). Thyrotropin-releasing hormone (TRH), another putative inhibitory neurotransmitter in several areas of the mammalian CNS (Collu et al., 1977), is capable of antagonizing ethanol-induced sleep (Breese et al., 1975) and of modifying psychomotor activity in rats (Segal and Mandell, 1974).It has been found to antagonize pentobarbitalinduced sleep (Breese et al., 1975) and pentobarbital- or morphineinduced growth hormone $(\mathrm{GH})$ and prolactin (PRL) release in rats (Collu et al., 1975; 1976; Taché et al., 1977). It was decided to investigate the interaction of taurine with pentobarbital or morphine in rats. Demonstration of another mode of action of taurine could help delineate its possible role in a disease such as Friedreich's ataxia (Barbeau, 1976).

\section{MATERIALS AND METHODS}

Adult, male Sprague-Dawley rats 200-300 g b.w. were purchased from Canadian Breeding Farm (St. Constant, Québec) and housed under conditions of controlled lighting (lights on at 6:00 h, out at 18:00 h) and temperature $\left(22^{\circ} \mathrm{C}, 60 \% \mathrm{~h}\right.$ ' midity). They were fed rat pellet. and given tap water ad libitum. Three experiments were performed.

1. Effect of taurine on pentobarbital induced sleep.

Two groups of rats, 10 animals each, were used for this experiment. Experimental animals were injected IP at 0 min with taurine 36 $\mathrm{m} / \mathrm{moles} / \mathrm{kg}$ dissolved in saline 4 $\mathrm{ml} / \mathrm{kg}$, while controls received the same amount of saline. Five min later both groups received pentobarbital $50 \mathrm{mg} / \mathrm{kg}$ i.p. Onset of sleep was determined by the loss of the righting reflex and duration of sleep was computed until reappearance of the reflex.

2. Effect of taurine on pentobarbital-induced pituitary hormone release.

Four groups of rats, 10 animals each, were used for this experiment. All animals were chronically implanted, according to stereotaxic coordinates, with a cannula allowing the injection of substances into the right lateral ventricle of the brain (Hayden et al., 1966). Forty eight hours later they received an intracerebroventricular (IVT) injection of either taurine $10 \mu$ moles/rat in $10 \mu 1$ saline, or saline. Five min 
TABLE 1

Effects of taurine ${ }^{a}$ on the onset and duration of sleep induced by pentobarbital ${ }^{b}$.
1 Saline + pentobarbital 10

2 Taurine + pentobarbital 10

\section{Number \\ of \\ rats}

rats

awake

\section{Onset of}

min

Duration of

min

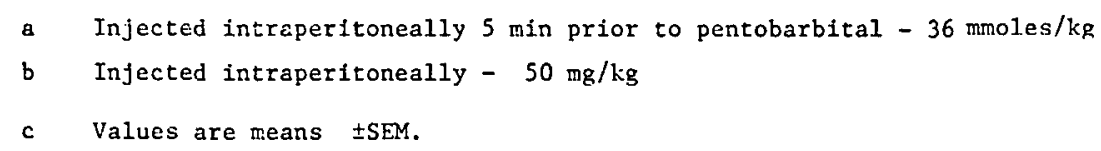

later they were injected i.p. with either pentobarbital $50 \mathrm{mg} / \mathrm{kg}$, or saline. All groups were sacrificed by decapitation $15 \mathrm{~min}$ after the last injection, and the trunk blood was collected in heparinized tubes. Plasmas were separated by centrifugation and stored at $-20^{\circ} \mathrm{C}$ until hormonal determinations were per-

TABLE 2

Effects of taurine ${ }^{a}$ on plasma GH, PRL, and FSH levels

in rats treated with pentobarbital ${ }^{b}$.

\begin{tabular}{cccccc}
\hline Group & \multicolumn{1}{c}{ Treatment } & $\begin{array}{c}\text { Number } \\
\text { of } \\
\text { rats }\end{array}$ & GH & PRL & FSH \\
\hline & & & & & \\
1 & Saline + Saline & 10 & $62 \pm 24^{c}$ & $10 \pm 2$ & $626 \pm 35$ \\
2 & Saline + Pentobarbital & 10 & $131 \pm 22$ & $38 \pm 10 *$ & $489 \pm 33$ \\
3 & Taurine + Saline & 10 & $67 \pm 20$ & $14 \pm 3$ & $407 \pm 41 * *$ \\
4 & Taurine + Pentobarbital & 10 & $91 \pm 24$ & $43 \pm 10$ & $659 \pm 92(*)$
\end{tabular}

expressed in terms of the respective NIAMDD-RP-1 standards.

3. Effects of taurine on morphine-induced pituitary hormone release.

The same protocol as in experiment 2 was followed. However, the rats were injected with morphine 10 $\mathrm{mg} / \mathrm{kg}$ IP instead of pentobarbital. Plasma levels of GH, PRL and FSH were measured as in experiment 2.

Statistical probabilities were calculated by Student's " $t$ " test or one-way analysis of variance.

\section{RESULTS}

1. Effect of taurine on pentobarbital-induced sleep.

As shown in Table 1, neither the number of rats remaining awake, nor the duration of sleep was modified by taurine. Onset of sleep was more rapid in taurine-treated rats, but statistical significance was not reached.

2. Effects of taurine on pentobarbital-induced pituitary hormone release.

As shown in Table 2, although plasma $\mathrm{GH}$ levels more than doubled under pentobarbital, only the increase in PRL levels reached statistical significance. This effect was not influenced by taurine. In non anesthetized rats, only plasma FSH values were modified by taurine which induced a significant decrease.

\section{Effects of taurine on morphine- induced pituitary hormone re- lease.}

After morphine administration plasma GH levels were increased (Table 3). This stimulatory effect was completely inhibited by prior administration of taurine. No significant changes were observed in plasma values of PRL or FSH.

\section{DISCUSSION}

The administration of small amounts of the amino acid taurine either IP or IVT failed to influence either sleep or pituitary hormone release induced by pentobarbital. The large increase in plasma $\mathrm{GH}$ values induced by morphine was completely inhibited by the prior IVT injection of taurine. Only the levels 
of FSH were affected, though inconsistently, by the amino acid injected in animals not treated with pentobarbital or morphine.

The powerful stimulating action of morphine on $\mathrm{GH}$ secretion confirms data previously obtained by several laboratories (Simon et al., 1973; Collu et al., 1976). Although the mechanism of this effect is unknown, it appears to be exerted through the CNS rather than directly on the pituitary gland (Ferland et al., 1977). Since morphine has been found to modify the metabolism of brain catecholamines and indoleamines (Yarbrough et al., 1971; Johnson et al., 1974), which are implicated in the control of $\mathrm{GH}$ secretion (Collu et al., 1972), it has been suggested that the GH-stimulating action is exerted through CNS monoaminergic pathways (Collu et al., 1976). Whether taurine antagonism of morphine hormonal action is also exerted through the same pathways has still to be demonstrated. It is interesting that the hypothermic effect of an IVT injection of taurine was reduced by treating the animals with pchloro-phenylalanine which depletes most of the brain serotonin (Sgaragli et al., 1975), Other mechanisms of taurine's inhibitory action might be antagonism at the opiate receptor level or, more unlikely, increased metabolism or excretion of morphine. Whether taurine interferes with some other morphinedependent effects such as analgesia and tolerance, or antagonizes the effects of endogenous opiate-like peptides such as endorphins (Taché et al., 1977), is of interest. In view of the high incidence of abnormal glucose tolerance curves (Shapcott et al., 1976) and the possible defect in taurine metabolism in Friedreich's ataxia (Lemieux et al., 1976) GH secretion and control should be studied in that disease.

\section{ACKNOWLEDGMENTS}

The authors wish to thank the NIAMDD, Rat Pituitary Hormone Program and Dr. A. F, Parlow for the generous allocation of materials for hormone radio-immunoassays. The technical assistance of Mrs. H. Guillet and the secretarial help of Miss. S. Beaudet is gratefully acknowledged. This work was supported

\begin{abstract}
TABLE 3
Effects of taurine ${ }^{a}$ on plasma GH, PRL and FSH levels

In rats treated with morphine ${ }^{b}$.
\end{abstract}

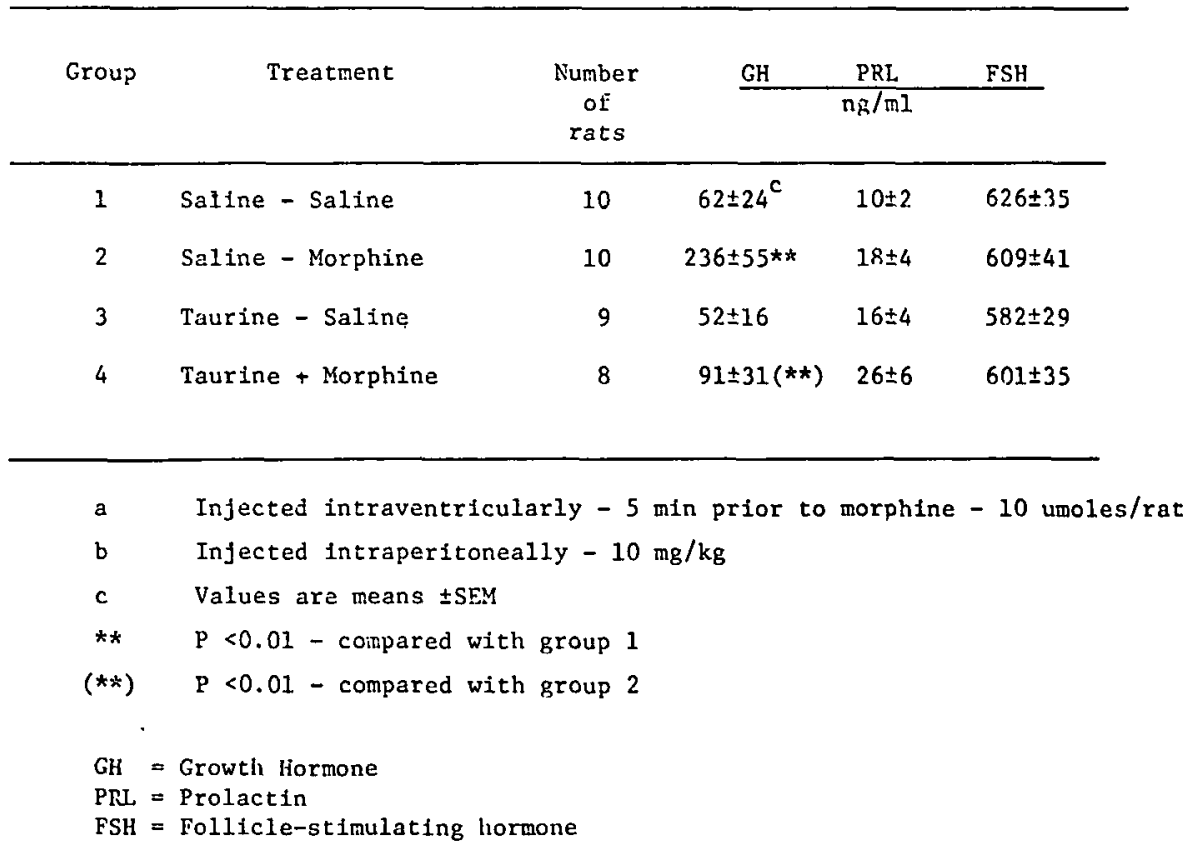

by Medical Research Council of Canada Grant MA-4691 and by a Grant from l'Association Canadienne de l'Ataxie de Friedreich.

\section{REFERENCES}

BARBEAU, A. (1976). Friedreich's ataxia 1976 - An overview. Can. J. Neurol. Sci., 3, 389-397.

BASKIN, S. I., HINKAMP, D. L., MARQUIS, W. J. and TILSON, H. A. (1974). Effects of taurine on psychomotor activity in the rat. Neuropharmacol., 13, 591-594.

BONAVENTURE, N., WIOLAND, N. and BEZAUT, M. (1974). Nouvelles données sur le rôle de la taurine et du GABA comme neurotransmetteurs inhibiteurs dans la rétine. J. Physiol. (Paris), 63, 228A.

BREESE, G. R., COTT, J. M., COOPER, B. R., PRANGE, A. J. Jr., LIPTON, M. A. and PLOTNIKOFF, N. P. (1975). Effects of thyrotropin-releasing hormone (TRH) on the actions of pentobarbital and other centrally acting drugs. J. Pharmacol. Exp. Ther., 193, 11-22.

COLLU, R., FRASCHINI, F., VISCONTI, P. and MARTINI, L. (1972). Adrenergic and serotoninergic control of growth hormone secretion in adult male rats. Endocrinology, 90, 1231-1237.

COLLU, R., CLERMONT, M. J., LETARTE, J., LEBOEUF, G. and DUCHARME, J. R. (1975). Inhibition of pentobarbital-induced release or growth hormone by thyrotropin-releasing hormone. Endocr. Res. Commun., 2, 123-135.
COLLU, R., CLERMONT, M. J., and DUCHARME, J. R. (1976). Effects of thyrotropin-releasing hormone on prolactin, growth hormone and corticosterone secretions in adult male rats treated with pentobarbital or morphine. Eur. J. Pharmacol., 37, 133-140.

COLlU, R., DU RUISSEAU, P., TACHE, $Y$. and DUCHARME, J. R. (1977). Thyrotropin-releasing hormone in rat brain: nycthemeral variations. Endocrinology, 100, 1391-1393.

CRABAI, F., SITZIA, A., PEPEU, G. (1974). Taurine concentration in the neurohypophysis of different animal species. J. Neurochem., 23, 1091-1092.

DAVISON, A. N. and KACZMAREK, L. K. (1971). Taurine-A possible neurotransmitter. Nature, 234, 107-108.

FERLAND, L., LABRIE, F., ARIMURA, A. and SCHALLY, A. V. (1977). Stimulated release of hypothalamic growth hormone-releasing activity by morphine and pentobarbital. Mol. Cell. Endocrinol., $6,247-252$.

GUIDOTTI, A., BADIANI, G. and PEPEU, G. (1972). Taurine distribution in cat brain. J. Neurochem., 6, 247-435.

HAYDEN, J. F., JOHNSON, L. R. and MAICKEL., R. P. (1966). Construction and implantation of a permanent cannula for making injections into the lateral ventricle of the rat brain. Life Sci., 5, 1509-1515.

HUXTABLE, R, and BARBEAU, A. Eds. (1976). Taurine, Raven Press, New York, pp. 1-398 
IIDA, S. and HIKICHI, M. (1976). Effect of taurine on ethanol-induced sleeping time in mice. J. Stud. Alcohol, 37, 19-26.

JACOBSEN, J. G. and SMITH, L. L. H. (1968). Biochemistry and physiology of taurine and taurine derivatives. Physiol. Rev., 48, 424-511.

JOHNSON, J. C., RATNER, M., GOLD, G. J. and CLOUET, D. H. (1974). Morphine effects on the levels and turnover of catecholamines in rat brain. Res. Comm. Chem. Path. Pharmacol., 9, 41-53.

LEMIEUX, B., BARBEAU, A., BERONIADE, V., SHAPCOTT, D., BRETON, G., GEOFFROY, G., and MELANCON, S. (1976). Amino Acid Metabolism in Friedreich's Ataxia.. Can. J. Neurol. Sci., 3, 373-378.

PERRY, T. L., BERRY U., HANSEN, S., DIAMOND, S. and MOK, C. (1971). Reg- ional distribution of amino acids in human brain obtained at autopsy. J. Neurochem., 18, 513-519.

SEGAL, D. S. and MANDELL, A. J. (1974). In: The thyroid axis, drugs and behavior. A. J. Prange (ed.), Raven Press, New York, pp. 129-133.

SGARAGLI, G. P., PAVAN, F. and GALLI, A. (1975). Is taurine-induced hypothermia in the rat mediated by 5-HT? Naunyn-Schmiedeberg's. Arch. Pharmacol., 288, 179-184.

SHAPCOTT, D., MELANCON, S., BUTTERWORTH, R., KHOURY, K., COLLU, R., BRETON, G., GEOFFROY, G., LEMIEUX, B. and BARBEAU, A. (1976). Glucose and insulin metabolism in Friedreich's ataxia. Can. J. Neurol. Sci., 3, 361-364.

SIMON, M., GARCIA, J. F. and GEORGE,
R. (1973). Effects of morphine on regional levels of brain 5-HT, NE, and DA as correlated with anterior pituitary hormone levels in plasma. Proc. West. Pharmacol. Soc., 16. 19-24.

TACHE, Y., DU RUISSEAU, P., DUCHARME, J. R. and COLLU, R. (1977). Antagonism of pentobarbitalinduced hormonal changes by TRH in rats. Eur. J. Pharmacol. 45, 369-376.

TACHE, Y., LIS, M. and COLLU, R. (1977). Effects of thyrotropin-releasing hormone on behavioral and hormonal changes induced by $\beta$-endorphin. Life Sci., 21, 841-845.

YARBROUGH, C. G., BUXBAUM, D. M. and SANDERS-BUSH, E. (1971). Increased serotonin turnover in the acutely morphine treated rat. Life Sci., 10, 977-983. 